\title{
TEKANAN STRUKTURAL, PELUANG POLITIK, DAN SUKSES GERAKAN PETANI DI LAMPUNG
}

\section{(THE STRUCTURAL PRESSURE, POLITICAL OPPORTUNITY, AND SUCCESSFUL OF PEASANT MOVEMENT IN LAMPUNG)}

\author{
Hartoyo \\ Jurusan Sosiologi \\ Fakultas Ilmu Sosial dan Ilmu Politik \\ Universitas Lampung \\ Email: htyiluh@yahoo.co.id
}

\begin{abstract}
This study was aimed at explaining one of the conflicts in Lampung Province who developed into a peasant movement. Interestingly, this peasant movement overran the land and agrarian policy influence to form a new village. Data were obtained from depth interviews and documentary studies. The results found that the structural pressures led to the accumulation of land conflicts crystallize into "sub-culture of peasant opposition." Its social and cultural capital were a base to accelerate the strengthening of peasants' resource mobilization. The momentum of the political opportunities at the beginning of reform responded quickly to the socio-political movements in the form of protests, negotiations and land occupation. Through this movement, the farmers has managed to occupy agricultural land, the agrarian policy changes that benefit farmers and obtained the legality of the formation of a new village Karang Rejo. However, behind this success, the substantive isues of peasants to land ownership was still neglected, so that the struggle of peasants were still not finished.
\end{abstract}

Key words: land conflict, peasant movement, movement outcome

\section{PENDAHULUAN}

Konflik pertanahan dan gerakan petani merupakan dua fenomena yang marak terjadi di Lampung, terutama setelah jatuhnya rezim Orde Baru. Konflikkonflik tersebut bersifat akumulatif dan sebagaian besar diikuti aksi pendudukan lahan (Koridor, 2002). Aksi-aksi tersebut sebagian dilakukan secara sistematis dan terorganisir. Pada tahun 2009 konflik pertanahan di Lampung menduduki peringkat kedua di Indonesia setelah Nusa Tenggara Timur (Mukri Friatna. 2009).

Konflik-konflik pertanahan di Lampung sebagian besar bersifat vertikal dan asimetris, yakni terjadi dalam struktur hubungan antara pihak-pihak yang tidak sama kekuatannya antara petani berhubungan dengan negara dan perusahaan. Ini terjadi karena tujuan masing-masing pihak tidak bersesuaian dan mereka saling mengekspresikan naluri permusuhan. Rasa permusuhan

80 | Hartoyo. Tekanan Struktural, Peluang Politik, dan Sukses Gerakan Petani... 
membutuhkan saluran bertindak baik dengan cara damai maupun paksaan (Bartos dan Wehr, 2003:13-26). Realitas seperti ini di negara-negara berkembang sebagai produk sampingan dari dampak modernisasi-pembangunan (Hugh Miall, 2000:18).

Konflik pertanahan berkembang menjadi gerakan petani dalam dua bentuk, yakni sebagai wujud agresifitas atas rasa frustasi petani, dan dalam rangka merubah posisi tawarnya untuk melakukan tekanan ke atas guna melancarkan tuntutan-tuntutannya. Bentuk pertama terjadi akibat semakin kuatnya hambatan tercapainya tuntutan-tuntutan petani sehingga beban psikologis mereka semakin terakumulasi, solidaritas semakin menguat, dan semakin mendorong perilaku agresif. Bentuk kedua terjadi dengan bantuan pihak ketiga untuk meningkatkan posisi tawar petani, sehingga peluang penyelesaian konflik pertanahan menjadi lebih besar dibanding pada posisi semula (Marzali, 2002:20-21).

Pertautan bentuk pertama berkembang menjadi bentuk kedua dalam penelitian Ngadisah (2003:309-311) karena memenuhi syarat kepemimpinan, syarat politis, syarat teknis, dan syarat lingkungan strategis. Hasil penelitian Wahyudi (2005:264-266) juga menemukan pentingnya jejaring (networks) eksternal, meskipun konsep tersebut perlu dibedakan dengan konsep koalisi (coalition) seperti dalam penelitian Rochman (2002:11-12). Dalam kasus lain, Victor Silaen (2006:195-281) menemukan pengaruh faktor kultural sebagai spirit perjuangan dan isu-isu lokal sebagai landasan perjuangan.

Pada tataran teoritis, teori-teori utama gerakan sosial memiliki fokus yang berbeda dalam menjelaskan hubungan antara konflik struktural berkembang menjadi gerakan petani. Menurut teori frustasi-agresi, rasa ketidakadilan dapat menyebabkan terjadinya frustasi dan berkembang menjadi agresi (Gurr, 1970:33). Sedangkan teori deprivasi relatif menyatakan bahwa meningkatnya deprivasi relatif mendorong berkembangnya rasa frustasi, kemudian pada derajat kemarahan dan perlawanan (Barkan and Snowden, 2001:17). Secara umum teori-teori psikologi sosial tersebut menyatakan bahwa kuatnya tekanan struktural dapat memunculkan konflik-konflik pertanahan yang berkembang menjadi gerakan petani.

Mengacu pendapat Smelser (1963), derajat tekanan struktural yang dapat memunculkan gerakan petani harus didukung oleh kondusifitas struktural, ketegangan struktural, dan lemahnya kontrol sosial. Sedangkan dalam perspektif mobilisasi sumberdaya, bahwa tekanan struktural tersebut menjadi basis upaya meningkatkan komitmen anggota, dalam memperoleh dukungan publik, dan dapat memperkuat gerakan. Derajat tekanan dan jatuhnya korban dapat meningkatkan simpati publik dan dukungan material, sehingga dapat meningkatkan manfaat dan menurunkan biaya partisipasi dalam gerakan (McAdam and Snow, 1997: 190). Menurut Mc Adam (1988: 134), proses ini sebagai "jembatan struktural yang memediasi hubungan antara kondisi politik makro dan keputusan individual untuk bertindak terhadap kondisi tersebut". Salah satu basis perspektif mobilisasi sumberdaya adalah teori pilihan rasional. Posisi gerakan sosial lebih dilihat sebagai tindakan kolektif instrumental dalam 
melakukan perubahan daripada tindakan ekspresif (Barkan and Snowden, 2001: 6).

Penguatan struktur gerakan petani berkaitan dengan struktur peluang politik. Respon terhadap peluang politik bersifat dinamis, dan terkait dengan ruang dan waktu. Artinya "institutionalized politics" menentukan struktur peluang dan hambatan bagi berkembangnya gerakan (McAdam dan Scott, 2002). Jadi, ruang dan proses politik dapat meningkatkan kapasitas dalam mempengaruhi keputusan yang lebih baik bagi pencapaian kepentingan gerakan (Dubet and Thaler, 2004: 559). Gerakan petani muncul ketika terjadi perubahan iklim politik reformasi yang membuat aksi-aksi kolektif lebih memungkinkan untuk sukses. Peluang politik meningkat pada level penerimaan para elit terhadap aksi-aksi kolektif atau dalam rangka penstrukturan kembali hubungan-hubungan kekuasaan yang ada (Olzak dan Ryo, 2004).

Di dalam proses mobilisasi sumberdaya dan tindakan kolektif terjadi proses pembingkaian (framing) kolektif. Snow et.al. (1986) dan Snow dan Benford (1988) (dalam Hjlmar,1996) menggunakan konsep frame alignment untuk menggambarkan katerkaitan timbal balik antara frame koqnitif individu partisipan dengan frame ideologis. Konsep frame alignment dalam beberapa hal sama dengan konsep "concensus mobilization", menunjuk pada usaha yang dilakukan oleh organisasi gerakan dalam praktek mobilisasi untuk menciptakan konsensus nilai-nilai. Bedanya, mobilisasi konsensus menekankan pada sumberdaya organisasi dan kapasitasnya untuk menciptakan konsensus, sedangkan frame alignment lebih memfokuskan pada derajat kesamaan antara pilihan frame individu partisipan dengan organisasi gerakan (Hjlmar,1996). Dalam gelombang gerakan sosial, frame kolektif bukan hanya berupa kumpulan sikap dan persepsi individu (agregate), tetapi juga sebagai hasil dari negosiasi makna bersama. Komitmen terhadap hasil framing tersebut kemudian menjadi acuan bersama dalam aksi-aksi kolektif (Benford dan Snow, 2000: 614).

Sama dengan gerakan sosial lainnya, tujuan umum gerakan petani adalah kapasitasnya dalam melakukan berbagai jenis perubahan. Gerakan sosio-politik petani merupakan gerakan jangka pendek yang lebih terfokus pada perubahan kebijakan struktur agraria, sedangkan gerakan sosio-kultural bersifat jangka panjang bertujuan untuk merubah kondisi kultur yang lebih luas dan dapat mencapai suatu identitas kolektif (Johnston dan Klendermans, 1995).

Kajian ini bertujuan menjelaskan bagaimana konflik pertanahan di wilayah Register 40 Gedung Wani berkembang menjadi gerakan sosio-politik petani, dan bagaimana gerakan tersebut berhasil menguasai tanah dan membentuk desa baru Karang Rejo. Konflik pertanahan di wilayah ini pertama muncul pada tahun 1976. Pada tahun 1996 konflik kembali terjadi dan puncaknya terjadi tahun 1998 yang berkembang menjadi gerakan sosio-politik petani. 


\section{METODE PENELITIAN}

Kajian ini menggunakan analisis deskriptif kualitatif yang didekati dengan paradigma metodologi konstruktivisme dan historis sosiologis. Studi kasus terhadap konflik pertanahan dan gerakan petani di Register 40 Gedung Wani secara khusus dipilih sebagai strategi penelitian, karena wilayah desa Karang Rejo (hasil pendudukan) kecamatan Jati Agung, kabupaten Lampung Selatan berada di wilayah tersebut. Data dikumpulkan melalui wawancara mendalam, perekaman dan dokumentasi. Sumber data diperoleh dari LSM, organisasi gerakan petani, perusahaan, instansi pemerintah, perguruan tinggi, aktivis gerakan, dan petani di wilayah sengketa (desa Karang Rejo dan sekitarnya). Dalam proses pengumpulan dan analisis data dilakukan dialog dengan para informan sehingga cenderung pada pendekatan konstruktivis. Pilihan pada pendekatan ini didasarkan pada asumsi menempatkan realitas konflik pertanahan dan gerakan petani sebagai hasil bekerjanya proses pembingkian kolektif yang di dalamnya melibatkan berbagai proses pemaknaan subyektif dan intersubyektif.

\section{HASIL DAN PEMBAHASAN}

\section{Awal Munculnya Konflik Pertanahan}

Desa Karang Rejo merupakan bagian dari wilayah Register 40 Gedung Wani. Sebelum menjadi desa definitif tahun 2004, pada tahun 1960-an wilayah ini sudah dibuka oleh petani atas ijin dari Dinas Kehutanan Provinsi Lampung. Lahan dibuka melalui kepala-kepala areal pemegang ijin, dengan ijin-ijin pembukaan hutan untuk lahan pertanian. Contohnya, di dalam surat ijin yang dimiliki oleh petani terdapat klausul bahwa pemerintah menjanjikan akan meningkatkan status lahan garapan petani menjadi hak miliknya jika dikelola dengan baik dan benar sesuai aturan.

"...bila sipemegang surat idzin memenuhi Peraturan2 tersebut, sebalik-baiknja maka Dinas Kehutanan akan mengusahakan agar dalam waktu jang sesingkat mungkin tanah ini mendjadi hak miliknja."

Pada tahun 1974 Gubernur Lampung mengeluarkan kebijakan tidak akan mengganggu gugat semua kampung-kampung yang sudah ada atau telah disyahkan oleh Pemerintah Daerah yang berada di dalam kawasan kehutanan, termasuk lahan pertanian yang terpelihara secara produktif dan telah diolah selama minimal 2 (dua) tahun. Pada tahun 1976 kebijakan tersebut dimentahkan oleh pemerintah pusat dengan memberi ijin HGU kepada suatu perusahaan untuk mengelola wilayah tersebut selama 20 tahun. Pada hari Jum'at 23 Juli 1976 tanaman petani digusur habis, dan pada hari Senin 26 Juli 1976 mereka mengalami teror dan ancaman. Banyak petani yang mengungsi termasuk Kepala Kampung dan baru kembali setelah dibujuk oleh Camat Kedaton.

Selama itu petani hanya bisa pasrah karena posisinya sangat lemah dan sering mendapat tekanan dari aparat keamanan. Setelah habis masa HGU, 
warga setempat banyak yang membuka lahan kembali untuk bercocok tanam. Seorang petani dari desa Sukadamai mengatakan:

Tanaman perusahaan yang sudah tidak produktif saat itu digarap masyarakat dan yang menyuruh juga orang perusahaan sendiri. Tahun 1995/1996 tanaman masyarakat dibajak oleh perusahaan, yaitu tanah bekas yang dulunya dikontrak perusahaan.

Pada pihak lain, sebelum tahun 1996 perusahaan sudah menanami pohon hutan tanaman industri (HTI) pada lahan-lahan yang tidak digarap oleh petani. Upaya tersebut ternyata terkait dengan kepentingan selanjutnya untuk bisa menguasai lahan yang lebih luas. Kepentingan tersebut terwujud, yakni pada tanggal 31 Juli tahun 1996 masuklah perusahaan lain setelah memperoleh ijin HGU dari Menteri Kehutanan RI Nomor 388/kpts-II/1996. Ini adalah perusahaan baru yang dibentuk hasil kerjasama antara perusahaan lama dengan PT Inhutani V. Perusahaan ini diberi hak pengusahaan seluas sekitar 41.210 hektar yang akan ditanami tanaman hutan.

Masyarakat menjadi resah karena dengan luas wilayah yang dikuasai perusahaan tersebut berarti termasuk wilayah desa-desa yang sudah ada yang sekarang mereka huni, termasuk lahan-lahan yang sudah mereka garap. Tindakan represif terus dilancarkan guna membatasi akses penduduk sekitar terhadap lahan-lahan di kawasan hutan. Seorang tokoh petani dari desa Sinar Rejeki mengatakan:

Karena waktu itu masih Orde Baru ya para petani dengan gampang dicap macammacam dan dengan mudah diredam dengan paksaan. Ya, mungkin petani bisa dinilai sebagai tindakan miring. Perusahaan sendiri memang isunya kan itu dan tentara itupun ya begitulah suaranya. Masyarakat menjadi marah ketika mereka distempel PKI atau BTI oleh aparat keamanan.

Upaya mediasi telah dilakukan oleh pemerintah kabupaten dan diperoleh kesepakatan bahwa petani boleh melakukan tanaman tumpangsari seluas 300 hektar. Tetapi, dalam praktek dilapangan pihak perusahaan secara sepihak mengingkari kesepakatan tersebut. Perusahaan tetap menjaga ketat terhadap lahan yang dikelolanya, dan memberikan sangsi tegas setiap terjadi pelanggaran oleh masyarakat sekitar. Namun demikian, upaya petani untuk dapat menggarap lahan perusahaan tetap dilakukan. Ketua organisasi tani di wilayah Register 40 Gedung Wani mengatakan:

Usaha petani disini, paling tidak untuk dapat menggarap lahan perusahaan terus dilakukan meskipun masih terbatas pada tingkat kabupatan (Lampung Selatan). Memang waktu itu sudah ada kesediaan dari Kodim yang akan meneruskan usulan ke tingkat provinsi setelah selesai di tingkat kabupaten. Tetapi, selelah berjalan hampir tiga tahun (1996-1998) ternyata belum juga ada tanda-tanda tindak lanjutnya.

Fenomena di atas sebagai indikasi bahwa tanah dikuasai oleh negara dan kemudian akses terhadap tanah dibuka lebar kepada para pengusaha, meskipun harus mengusir petani. Saluran politik dan hukum disumbat, serta berbagai macam stigma politik dilancarkan untuk menekan protes petani. Kondisi ini

84 | Hartoyo. Tekanan Struktural, Peluang Politik, dan Sukses Gerakan Petani... 
berdampak pada akumulasi beban psikologis, ekonomis dan sosio-kultural yang dalam, dan bersamaan dengan itu jumlah petani tidak bertanah terus bertambah. Banyak petani yang frustasi karena persoalan pertanahan yang mereka hadapi tidak pernah terselesaikan secara tuntas. Seorang tokoh petani dari desa Sukadamai mengatakan:

Tahun 1997 kerasnya perlakuan perusahaan terhadap petani, semua tanaman digusur dan yang menggarap disitu ditangkapi. Saya selaku anak membela orang tua, dan akhirnya saya dibawa juga. Saya katakan pada Koramil: "Kalau kami menyerobot tanah kan tidak di bawa pulang pak. Kalau memang mau diambil tinggal tanda tangan saja kami tidak boleh menggarap begitu kan beres. Tetapi kenapa kami harus ditahan segala". Mereka mengatakan "ya sudah", kemudian kami dilepaskan dengan menandatangani surat pernyataan di atas meterai".

\section{Tekanan Struktural dan Marginalisasi Petani dalam Sistem Agraria Dominan}

Perbedaan realitas hubungan teknis berposisi sejajar dengan hubungan sosial agraria. Tekanan struktural yang kuat terhadap petani berjalan seiring dengan semakin terbuka peluang bagi para pengusaha untuk menguasai tanah, termasuk tanah-tanah yang sudah lama dikuasai dan dikelola secara produktif oleh petani. Kondisi ini mengarah pada berkembangnya ketegangan struktural antara petani berhubungan dengan negara dan perusahaan. Tindakan represif terus menerus oleh aparatus negara menyebabkan petani menjadi frustasi dan berkembang perilaku melawan. Perlawanan petani pada masa Orde Baru cenderung ekspresif sebagai bentuk reaksi bertahan atau reaksi balik, bersifat spontan, tidak terorganisir sehingga mudah dipatahkan. Realitas ini membelokkan arah sistem agraria dominan menjadi kontraproduktif terhadap tujuan pembangunan itu sendiri karena tidak sesuai dengan amanah UUD'45, khususnya Pasal 33 ayat (3).

Dilihat dari perspektif struktural, kondisi struktur agraria dominan Orde Baru tersebut berimplikasi pada akselerasi perubahan negatif bagi perbaikan nasib petani. Substansi sistem agraria dominan di dalamnya melekat sifat-sifat struktural yang cenderung meminggirkan kepentingan substantif dan posisi petani. Hubungan simbiosis mutualisme terjadi antara negara dengan perusahaan, sedangkan hubungan antagonis terjadi antara keduanya dengan masyarakat petani (Gambar 1). Akses petani terhadap tanah dibatasi, kontrol terhadap penguasaan tanah diperlemah, dan partisipasi disemukan. Hasilnya, partisipasi petani dalam penguasaan dan pengelolaan tanah menjadi menurun dan perolehan manfaat terhadap tanah sangat kecil. Sistem agraria domonan yang tidak setara dan adil tersebut gagal dalam mengatasi persoalan pertanahan bagi kesejahteraan petani.

Penjelasan di atas menunjukkan adanya tiga domain kesalahan struktural dalam sistem agraria dominan masa Orde Baru. Pertama, schemata interpretasi sistem agraria dominan oleh aparatus negara dikonsentrasikan pada "hasil" yang didukung oleh "alat", yakni pertumbuhan ekonomi yang didukung stabilitas politik (otoriter) dan sistem birokrasi (sentralistik). Konstruksi struktur signifikasi demikian mengabaikan praktek komunikasi partisipatif, dimana 


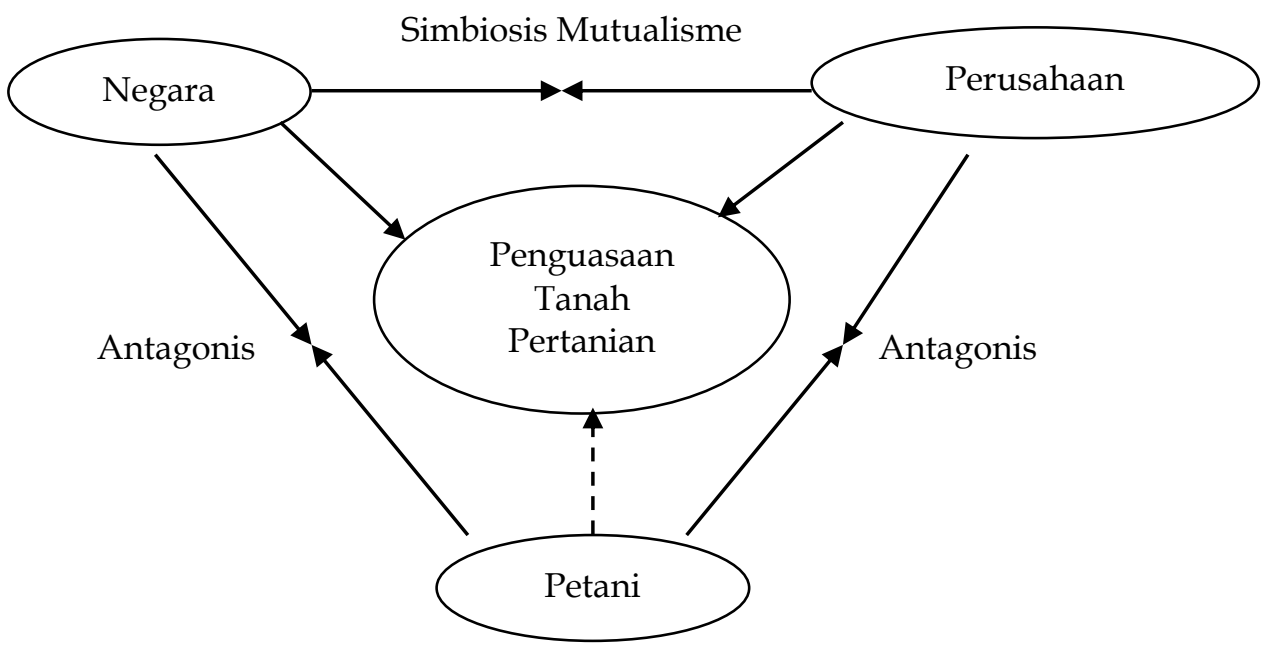

Gambar 1. Hubungan antar Elemen (Negara, Perusahaan dan Petani) dalam Sistem Agraria Dominan

petani yang menjadi bagian utama sistem agraria dominan justru mengalami peminggiran. Kedua, struktur dominasi agraria yang diwujudkan dalam praktek relasi kekuasaan (power) yang bersifat "distributive". Disini konsep "power" dimaknai sebagai kemampuan negara untuk memaksakan kehendak kepada petani. Konstruksi hubungan "power" yang demikian cenderung bersifat "zerosum", artinya hanya negara yang memiliki "power" dan petani tidak punya dan semakin kuat "power" negara berarti petani semakin kehilangan "power". Dalam hubungan "power" seperti ini, petani yang tidak dapat bekerjasama dengan negara dianggap sebagai penghambat pembangunan. Ketiga, konstruksi struktur legitimasi agraria yang mendukung sepenuhnya struktur signifikansi tersebut. Para penguasa dan pengusaha akan selalu berlindung di bawah peraturan perundangan yang berlaku yang memang diciptakan lebih berpihak pada kepentingan mereka.

Secara substantif praktek penguasaan tanah dalam sistem agraria dominan seperti itu menunjukkan adanya "sesat pikir", karena eksistensinya berjalan seiring dengan semakin banyak petani yang kehilangan tanahnya. Dengan demikian, perlawanan kolektif petani bukan karena kemiskinanya tetapi lebih karena meningkatnya kesadaran mereka terhadap tekanan-tekanan struktural. Konsekuensi dari tekanan struktural tersebut adalah berkembangnya ketegangan struktural, seperti eksistensi ambiguitas kebijakan agraria, meningkatnya deprivasi, ketegangan, dan konflik pertanahan (Ekstein, 1989:5).

Sistem agraria dominan yang memarginalkan petani menciptakan kapasitas kritisnya dalam mencerna dan menafsirkan konteks ruang (fisik dan sosio-kultural) yang mereka dihadapi. Semakin kuat tekanan struktural yang mengancamnya, maka petani semakin berusaha mengembangkan stok pengetahuan praktisnya, mengembangkan cara dan tindakan alternatif 
meskipun bersifat oposisi dengan sistem agraria dominan. Semua itu dilakukan dalam ruang kritis untuk mengatasi kebutuhan hidup yang bersifat dasar. Ini berarti bahwa pengetahuan, sikap dan perilaku petani tidak selalu harus sesuai dengan sistem agraria dominan yang selalu merugikan mereka. Suatu kondisi yang dirasa telah mengganggu melampaui batas toleransi kebutuhan dasar petani, maka mereka akan mencari berbagai cara untuk mengatasinya.

Selain itu, semakin menguatnya solidaritas, loyalitas dan komitmen moral menjadi pertanda telah disituasikannya identitas kolektif petani. Pendefinisian bersama tentang siapa "dirinya (in-groups)" dan siapa "pihak lawan (outgroups)" semakin menguat, sejalan dengan derajat tekanan dan ketegangan struktural. Semakin menguatnya kepercayaan bersama petani dan ketidakpercayaan terhadap aparatus negara juga berpengaruh terhadap formasi dan aktivasi konfliktual. Semua proses tersebut mendorong terbentuknya "sub kultur oposisi" petani. Modal sosial oposisional ini lebih dinamis dibanding kultur dominan, tetapi sifatnya kurang cair (fluid) dibanding frame kolektif. Di dalam sub kultur oposisi petani terdapat penguatan kesadaran konfliktual sejalan dengan kegagalan atas berbagai strategi perjuangan yang ditempuh sebelumnya. Sub kultur oposisi petani ini menjadi suatu "tool kit" yang sangat berguna untuk mengkonstruksi tindakan-tindakan strategis dalam perjuangan petani selanjutnya.

\section{Konsolidasi Internal dan Membangun Jejaring Eksternal}

Segera setelah gerakan-gerakan masyarakat sipil (civil society) dapat menumbangkan kekuatan rezim Orde Baru, maka momentum tersebut oleh petani dimaknai sebagai peluang politik untuk melanjutkan perjuangan. Situasi tersebut membuka kesadaran dan segera direspon dengan memperkuat jejaring ke dalam. Seorang tokoh petani dari desa Karang Rejo mengatakan:

Di desa Sukadamai dan sekitarnya, terdapat 9 orang pemrakarsa yang secara gigih dan intensif bergerak. Mereka ini yang kemudian didaulat sebagai tokoh perintis karena dianggap berjasa dalam mengawali perjuangan petani. Dari gerakan 9 orang tokoh inilah yang selanjutnya disebut "Tim Wali Songo" (Gerakan Wali Sembilan).

Penguatan jejaring ke dalam tersebut dengan cepat meluas ke desa-desa lain di sekitar wilayah Register 40 Gedung Wani. Proses rekruitmen anggota jaringan internal ini sejalan dengan semakin bertambahnya informasi adanya gerakan-gerakan demokrasi di kota Bandar Lampung. Semakin luas jaringan internal semakin menguatkan solidaritas dan komitmen moral perjuangan. Keberanian mereka bertambah dan siap melakukan tekanan ke atas.

Media informasi dan komunikasi dengan berbagai pihak juga digunakan untuk mempercepat dalam membangun jaringan eksternal. Ketua organisasi tani di wilayah Register 40 Gedung Wani mengatakan:

Kebingungan kami secara tidak sengaja akhirnya terpecahkan ketika salah seorang petani menemukan secarik kertas yang berisi lagu perjuangan. Lagu itu diyakini 
berasal Universitas Lampung, karena di sana sedang ada gerakan mahasiswa. Lagu itulah yang kemudian menjadi petunjuk adanya posko reformasi.

Dapat bertemu dengan para aktivis gerakan pro demokrasi merupakan langkah awal petani mendapat dukungan kuat dari organisasi masyarakat sipil (untuk selanjutnya disebut aktor "non petani"). Dengan membawa alat bukti surat-surat ijin pembukaan lahan, para wakil petani bersama aktor non petani pada tanggal 30 Juli 1988 berhasil melakukan aksi massa di Dinas Kehutanan Provinsi Lampung. Seorang tokoh petani yang ikut aksi mengatakan:

Kami ditanyai status penggarap disitu dan kami siap dengan surat-surat ijin pembukaan lahan yang ditanda tangani oleh Kepala Dinas Kehutanan Daerah Tingkat I Lampung. Tuntutan kami dapat menggarap kembali karena tanah itu adalah hasil bukaan kami. Kepala Kanwil Kehutanan sempat emosi, tetapi akhirnya dia berjanji akan datang untuk melakukan pengecekan di lapangan dalam waktu 15 hari paling lama.

Proses negosiasi berhasil dilakukan dan akhirnya pejabat kehutanan berjanji segera menyelesaikannya. Janji tersebut untuk sementara dipegang kuat oleh para petani dan dapat menurunkan derajat tekanan mereka.

\section{Penguatan Sumberdaya Mobilisasi: Pengorganisasian Petani Basis}

Janji pejabat kehutanan tersebut masih diragukan, karena peluang politik yang terbuka masih belum diimbangi dengan kekuatan sumberdaya mobilisasi yang cukup untuk meningkatkan posisi tawar dalam melancarkan tuntutannya. Keraguan ini didasarkan atas pengalaman gerakan mahasiswa dan trauma politik petani akibat berbagai tindakan represif yang dialami sebelumnya. Pertimbangan lainnya terkait dengan empat persoalan utama. Pertama, aksi pertama yang mendadak membuat pejabat instansi kehutanan menjadi terdesak, emosi dan terpaksa, sehingga janji yang diucapkan bersifat semu. Kedua, masih banyak konflik petanahan di Lampung yang belum terselesaikan. Ketiga, banyak konflik pertanahan yang berhubungan dengan kebijakan pemerintah pusat. Keempat, ruh paradigma pembangunan Orde Baru masih tertanam kuat dalam struktur mental para pejabat daerah.

Keraguan tersebut terbukti tidak ditepati, maka strategi gerakan diubah tidak lagi dikonsentrasikan di lingkungan kampus tetapi konsentrasikan di berbagai wilayah petani basis. Para aktor non petani secara aktif melakukan pendampingan, penyadaran dan merumuskan tuntutan-tuntutan sampai berhasil dibentuk organisasi petani tingkat basis, yang disebut "Posko". Ada tiga tuntutan utama petani di wilayah Register 40 Gedung Wani, yaitu: (1) hapuskan Hutan Tanaman Industri (HTI); (2) kembalikan tanah kepada rakyat dan konversikan desa-desa yang sudah definitif; dan (3) keluarkan status hukum tanah (sertifikat).

Strategi pengorganisasian petani basis juga dilakukan pada komunitas konflik pertanahan di berbagai wilayah lain. Karena kuatnya respon petani, maka dalam waktu kurang dari sebulan (Juli 1998) sudah terbentuk lebih dari 196 Posko. Semua Posko kemudian mengadakan pertemuan di Way Hurik

88 | Hartoyo. Tekanan Struktural, Peluang Politik, dan Sukses Gerakan Petani... 
Bandar Lampung dan berhasil disepakati membentuk suatu wadah dengan nama "Posko Reformasi Rakyat dan Mahasiswa Bersatu" (PRRMB). Ini merupakan wadah perjuangan awal petani bersama aktor non petani atau sebagai embrio lahirnya organisasi gerakan petani tingkat provinsi.

\section{Mobilisasi Sumberdaya: Melakukan Tekanan di Atas dan di Bawah}

Semakin kuatnya konsolidasi antar Posko, berjalan seiring dengan semakin kuatnya konsolidasi antar organisasi aktor non petani pendukungnya. Pada tanggal 12 Agustus 1998 berhasil dibentuk Dewan Rakyat Lampung (DRL), yakni suatu wadah organisasi "konsorsium" gabungan dari 36 elemen organisasi non petani yang mendukung gerakan rakyat, termasuk di dalamnya PRRMB.

Pada tanggal 25-26 Agustus 1998 berhasil dilakukan aksi massa di Kantor Gubernur Provinsi Lampung. Sasaran aksi terutama ditujukan kepada Gubernur Lampung. Dari proses negosiasi dengan para pejabat Pemda Provinsi Lampung berhasil dibentuk TIM 13. Anggotanya sebanyak 13 orang, yakni 5 orang dari Pemda Provinsi Lampung dan 8 orang dari DRL. Tugasnya adalah melakukan mediasi dalam proses penyelesesaian berbagai kasus konflik pertanahan di Provinsi Lampung, termasuk di wilayah Register 40 Gedung Wani.

Strategi aksi massa melakukan tekanan di atas ternyata kurang efektif dalam mempengaruhi sikap pemerintah dan perusahaan untuk segera merealisasikan tuntutannya. Sudah dua minggu TIM 13 bekerja, tetapi upaya mediasi belum membuahkan hasil dan belum ada respon positif dan nyata dari pemerintah dan perusahaan. Bahkan posisi dan semangat Tim 13 dinilai semakin melemah dilihat dari komitmennya dalam memperjuangkan kepentingan petani.

Pada tanggal 10 September 1998 dilakukan pertemuan dan berhasil disepakati perlu dilakukan aksi pendudukan lahan. Strategi ini dianggap sebagai langkah perjuangan yang strategis dan lebih efektif meskipun tetap membuka peluang bernegosiasi. Prinsip aksi yang disepekati adalah: "Satu aksi satu komando, komando hasil diskusi". Aksi pendudukan lahan dilakukan pada tanggal 13 - 17 September 1998 dan dikonsentrasikan di Register 40 Gedung Wani, yakni di lapangan Kebon Jeruk. Partisipan aksi tidak hanya dari para petani setempat tetapi juga didukung oleh berbagai Posko yang menjadi anggota PRRMB. Aksi massa dalam bentuk gotong-royong ini sebagai wujud kuatnya solidaritas sosial pada lingkup wilayah provinsi, sehingga lebih menguatkan posisi tawar petani dalam melakukan tekanan-tekanan.

Hingga Minggu malam tanggal 16 September 1998, upaya mediasi oleh TIM 13 belum membuahkan hasil. Dari hasil diskusi disepakati pernyataan sikap sebagai bentuk tekanan lebih kuat terhadap pemerintah daerah. Pernyataan sikap petani disampaikan oleh Sekretaris Posko Rejomulyo, sebagai berikut:

Apabila lahan ini tidak di serahkan, maka rakyat telah bertekad dan sepakat daripada mati lapar lebih baik mati terkapar bermandikan darah segar. 
Selain pernyataan sikap, juga diedarkan tanda tangan kepada seluruh warga masyarakat yang benar-benar ikut aksi. Tujuan pernyataan sikap dan tanda tangan untuk menjaga solidaritas sosial dan membantu semangat perjuangan para wakil petani dalam melakukan negosiasi dalam TIM 13. Tanda tangan tersebut juga dimaksudkan sebagai bukti jumlah peserta aksi pada masing-masing Posko.

Solidaritas sosial dan semangat juang petani dalam proses pendudukan lahan sempat menurun, karena mereka masih trauma terhadap pengalaman masa lalu atas tindakan represif yang dilakukan oleh aparat keamanan. Pada kondisi ini peran strategis para pemimpin (petani dan non petani) dibutuhkan dan melalui upaya persuasifnya mampu mengembalikan semangat petani untuk terus berpartisipasi aktif dalam aksi pendudukan lahan tersebut.

\section{Penguasaan Lahan Oleh Petani dan Terbentuknya Desa Baru Karang Rejo}

Pada hari Senin sore tanggal 17 September 1998 proses mediasi dan negosiasi yang dilakukan oleh Tim 13 berhasil mensepakati penyelesaian konflik pertanahan yang menguntungkan petani. Pada intinya lahan yang di mohon petani di sebagian wilayah Register 40 Gedung Wani yang masih dikelola perusahaan disetujui oleh Pemerintah Provinsi Lampung untuk diserahkan kepada petani.

Pada tanggal 18 September 1998 mulai dilakukan penebangan pohon Hutan Tanaman Industri (HTI). Tahap selanjutnya adalah mendirikan rumahrumah penduduk. Organisasi tani mengeluarkan kebijakan bahwa bagi warga sekitar di perbolehkan untuk membuat rumah di sepanjang tepian jalan "Jalur Kuning", dengan syarat: 1) membawa surat pindah dari desa asal disertai surat keterangan tidak memiliki lahan domisili dan lahan garapan; 2) organisasi tani yang akan menempatkan dan tidak dipungut biaya. Tindakan ini menurut pimpinan organisasi tani sebagai jawaban atas pertanyaan pemerintah:

Pendirian rumah-rumah itu sebenarnya untuk membuktikan pertanyaan pemerintah sendiri: "Apakah benar, masyarakat ini mengambil tanah benar-benar untuk masyarakat ?" Lha itu pertanyaan pemerintah kan begitu. Jadi kita menjawabnya tidak dengan kata-kata, tetapi dengan pembuktian di lapangan. Dengan perbuatan maka "dirikanlah rumah-rumah". Setelah banyak berdiri rumah-rumah menjadi sekelompok masyarakat, kemudian kita buat RT, Dusun, dan Desa.

Dari kebijakan tersebut maka dalam jangka waktu tiga bulan telah berdiri sekitar 900 rumah. Realitas ini kemudian dimanfaatkan oleh organisasi tani untuk membuat usulan kepada Pemerintah Provinsi Lampung agar wilayah tersebut di tetapkan menjadi desa. Melalui proses negosiasi, usulan dan pemantauan secara intensif terhadap perkembangan kebijakan agraria pusat dan daerah, akhirnya pada tanggal 19 Februari 2000 berhasil diperoleh Surat Keputusan Gubernur No: 06 Tahun 2000 yang menetapkan desa persiapan Karang Rejo sebagai pemekaran dari desa Karanganyar. Kemudian pada tanggal 11 Maret 2004 Bupati Lampung Selatan mengeluarkan Surat Keputusan tentang

90 | Hartoyo. Tekanan Struktural, Peluang Politik, dan Sukses Gerakan Petani... 
status definitif desa Karang Rejo dan menjadi bagian wilayah Kecamatan Jati Agung.

Pembagian lahan kepada para petani masih terus dilakukan yang dalam pelaksanaannya dipimpin oleh ketua Posko masing masing. Akan tetapi, disadari bahwa perjuangan petani di wilayah tersebut hingga saat ini masih belum selesai. Masih banyak persoalan internal yang dihadapi, terutama berkaitan dengan nasib petani miskin dalam pengusaan dan pengusahaan lahan hasil pendudukan tersebut. Persoalan yang lebih teknis tentang bagaimana cara pembagiannya, bagaimana hasil pembagian lahan, siapa yang banyak menguasainya, dan bagaimana status hukumnya (tuntutan ketiga) hingga saat ini masih belum terselesaikan secara tuntas di lapangan. Sebagian dari persoalan tersebut tersirat dari penuturan salah seorang pengurus organisasi tani, sebagai berikut:

"Daftar anggota basis hingga saat ini masih utuh seperti semula, dan jika anggotanya berganti bisa dicoret diganti anggota yang baru. Kalau organisasi tani tidak bisa tegas, ya percuma saja daftar anggota itu. Kalau caranya seperti itu maka orang yang lebih berkuasa bisa saja jual lahan sebanyak-banyaknya, karena semuanya bisa gelap mata. Siapa orangnya yang tidak ingin kekayaan ? Tetapi yang menjadi masalah kemudian adalah siapa yang akan menertibkan dan bagaimana caranya? Mengapa banyak orang lain yang mau membeli lahan dan apa alasan para anggota menjual lahannya ? Seharusnya semua itu segera dapat diatasi. Kalau memang ada anggota yang sudah tidak membutuhkan lahan, maka mereka dapat mengembalikan ke organisasi tani untuk membesarkan organisasi dalam melanjutkan perjuanganya. Setelah kembali ke organisasi kemudian organisasi yang menentukan lagi siapa yang berhak menerimanya. Kalau umpamanya organisasi ini tutup/bubar kemudian siapa lagi yang akan memperjuangkan mereka?"

Secara substantif, persoalan mendasar tersebut sebagai kritik terhadap lemahnya fungsi organisasi tani dalam pengelolaan tanah hasil pendudukan. Kondisi ini dikhawatirkan dapat mengancam posisi petani dalam penguasaan lahan. Kritik mendasar juga disampaikan oleh seorang tokoh petani:

"Masa lebih mudah mendapatkan lahan garapan daripada mempertahankanya". Kalau terjadi konflik antar warga, justru merupakan peluang bagus bagi pemerintah sebagai alasan untuk mengambil-alih lahan tersebut. Lama-kelamaan bosan juga pihak Kehutanan untuk selalu mengincarnya jika tidak ada konflik tanah antar warga masyarakat, tetapi jika terjadi sebaliknya merupakan kesempatan baik bagi pihak Kehutanan. Jika segenap warga masyarakat tetap kondusif, ada payung organisasinya yang kuat, maka tidak mudah digoyahkan oleh pihak lain."

Masalah tersebut pernah kemukakan kepada LSM Jakarta sebagai mitra agar membantu menfasilitasi dalam membuat Peraturan Desa (Perdes) Karang Rejo. Menurut mereka ide tersebut merupakan langkah yang tepat untuk mengatasi peliknya persoalan pertanahan hasil pendudukan di Karang Rejo. Dengan adanya Perdes maka persoalan penguasaan tanah dan pengelolannya 
diharapkan dapat di atasi dengan cepat dan efektif. Tetapi, ide tersebut sampai saat ini masih berupa wacana, belum terealisasikan.

\section{SIMPULAN}

Perjuangan petani di register 40 Gedung Wani berkembang menjadi gerakan sosio-politik merupakan titik kulminasi perlawanan petani akibat akumulasi tekanan dan ketegangan struktural dan marginalisasi petani. Situasi konfliktual tersebut menciptakan akumulatif kekecawaan sampai pada akhirnya membentuk sub kultur oposisi petani. Modal sosial oposisional ini menjadi landasan kuat dalam percepatan proses penguatan mobilisasi sumberdaya petani skala provinsi. Keberhasilan dalam membangun gerakan sosio-politik didukung oleh saling keterkaitan antara kekuatan sumberdaya mobilisasi, momentum peluang politik (era reformasi), spirit dan daya juang, dukungan para petani di berbagai wilayah lain, dan dukungan serentak dari segenap elemen masyarakat sipil (non petani).

Selain itu, ada dua hasil akhir yang secara faktual dicapai dari gerakan sosio-politik petani. Pertama, dapat dikuasai tanah pertanian oleh warga masyarakat yang sebelumnya dikuasai oleh perusahaan. Kedua, berhasil dikeluarkan kebijakan pemerintah daerah yang memperkuat posisi wilayah tersebut secara administratif menjadi desa definitif Karang Rejo, pecahan dari desa Karanganyar.

Akan tetapi, klaim keberhasilan tersebut masih menyisakan beberapa persoalan mendasar, khususnya berhubungan dengan visi awal gerakan petani, yakni mengentaskan nasib petani miskin. Salah satu kendala utamanya adalah lemahnya organisasi tani dalam menjawab persoalan tersebut pasca pendudukan lahan. Oleh sebab itu, selama kepentingan substantif petani terhadap tanah yang menjadi nafas kehidupan yang diperjuangkan belum mampu dijawab, maka keberhasilan gerakan sosio-politik petani tersebut masih bersifat semu dan perjuangan petani sebenarnya belum selesai.

\section{DAFTAR PUSTAKA}

Barkan, Steven. E., and Snowden, Lynne. L. 2001. Collective Violence. Allyn and Bacon.

Bartos, J.O., and Wehr, P. 2003. Using Conflict Theory. New York: Cambridge University Press.

Dubet, F., dan Thaler, H.L. 2004. Introduction: The Sociology of Collective Action Reconsidered. Corrent Sociology, July 2004, Vol. 52(4): 557-573 SAGE Publications. Download dari www.sagepublications.com.

92 | Hartoyo. Tekanan Struktural, Peluang Politik, dan Sukses Gerakan Petani... 
Eckstein S (ed). 1989. Power and Popular Protest: Latin American Social Movement. Berkeley: University of California Press.

Friatna, Mukri. 2009. Sumsel Urutan Ketujuh Konflik Tanah. Kompas. Com, Senin, 16 Nopember 2009. Dinduh dari http://regional.kompas.com/read/ 2009/11/16/1607387/sumsel.urutan. ketujuh. konflik.tanah.

Gurr, Robert. 1970. Why Men Rebel. New Jersey: Princenton University Press.

Hjlmar, Ulf. 1996. Constructivist Analysis and Movement Organizations: Conceptual Clarifications. Acta Sociologica 1996 Vol. 39, pp. 169-186.

Johnston H dan Klandermans B. Editor's. 1995. Social Movements and Cultur. Monnieapolis: University of Minnesota Press.

Marzali, Amri, 2002, Communal Conflicts In Contemporary Indonesia, Jakarta: Pusat Bahasa dan Budaya IAIN Jakarta dan The Knrad Adeneuer Foundation.

McAdam, Doug and David A. Snow. 1997. Social Movements: Reading on The Emergence, Mobilization, and Dynamics. Los Angeles, California: Roxbury Publishing Company.

McAdam, Doug dan Scott, W. Richard. 2002. Organizations and Movements. Makalah dipresentasikan dalam "The Annual Meeting of the American Sociological Association, Chicago", IL, August, 2002.

McAdam, Doug. 1988. Micromobilization Contexts and Recruitment to Activism. International Social Movement Research 1: 125-54.

Miall, Hugh. 2000. Resolusi Konflik Kontemporer: Penyelesaian, Mencegah, Melola dan Mengubah Konflik Bersumber Politik, Sosial, Agama dan Ras. Jakarta: PT. Raja Grafindo Persada.

Ngadisah. 2003. Konflik Pembangunan dan Gerakan Sosial Politik di Papua. Yogyakarta: Pustaka Raja.

Olzak, Susan and Ryo, Emily. 2004. Organization Diversity, Vitality and Outcomes in the Civil Right Movement: Running Head: Organizational Diversity in the Civil Rights Movement. Makalah disampaikan pada "Annual Meeting of the American Sociological Association in San Francisco, 2004.

Rochman, Meuthia Ganie. 2002. An Uphill Struggle: Advocacy NGO's under Soeharto's New Order, Jakarta: LabSosio, FISIP-Universitas Indonesia.

Silaen, Victor. 2006. Perlawanan Komunitas Lokal pada Kasus Indorayon di Toba Samosir: Gerakan Sosial Baru. Yogyakarta: IRE Press.

Smelser, Neil. 1963. Theory of Collective Behavior. New York: Free Press.

Surat Kabar Mingguan "Koridor", Edisi 178, Th. IV, 13 Oktober 2002.

Wahyudi. 2005. Formasi dan Struktur Gerakan Sosial Petani: Studi Kasus Reklaiming/Penjarahan Atas Tanah PTPN XII (Persero) Kalibakar Malang Selatan. Malang: UMM Press. 